\title{
IMAGENS DE PRESENTES/FANTASMAS DE PASSADOS
}

\author{
Brenda Carlos de Andrade \\ Universidade Federal Rural de Pernambuco
}

\begin{abstract}
Resumo:
A questão da representação de sujeitos nas Américas sempre constituiu um ponto de (des)encontros, convergências. Representar indígenas, escravos e/ou trabalhadores assalariados era uma atividade que incorporava muito de atitude etnográfica e que, no entanto, podia compor a caracterização de uma localidade. Neste trabalho, apresento uma seleção de três fotógrafos, Marc Ferrez, Christiano Junior e Martín Chambi, que contribuíram para formar uma imagem pessoal de determinados locais da América Latina. Os exemplos desses três artistas são comparados com a produção contemporânea da fotógrafa equatoriana Lucía Chiriboga, que incorpora fotos e documentos antigos em sua composição, dialogando diretamente com o passado.
\end{abstract}

Palavras-chave: Fotografia; Identidades; Memória.

\section{IMAGES OF PRESENTS/GHOSTS OF THE PAST}

\begin{abstract}
:
The representation of subjects in the Americas has always generated points of convergences, or divergences. To represent Indians, slaves or employees was an ethnographic decision that ultimately helped compose a particular characterization of a specific place. In this paper, I present a selection from three photographers-Marc Ferrez, Christiano Junior and Martín Chambi-whose contributions helped shape a personal / particular view of certain regions of Latin America. In a second moment, I confront these photographs with the works of contemporary Ecuadorian photographer Lucia Chiriboga, who incorporates antique photographs and documents in her art, in a direct dialogue with the past.
\end{abstract}

Keywords: Photography; Identities; Memory.

\section{Onde termina o ouroboros}

Numa casa de princípios do século $\mathrm{XX}$, situada no famoso bairro limenho de Barranco, encontra-se um curioso museu peruano. Entre suas salas de prataria sufocante e inusuais móveis coloniais, vê-se, na sala "Cuzco siglo XVIII", uma genealogia inca do século XVIII que, diferente da obra que lhe serviu de modelo, cortou a aparente continuidade entre os imperadores incas e os reis espanhóis eliminando estes últimos da composição. Do outro lado da cidade, no Museo de Ar- queología, Antropología e Historia, uma outra dessas pinturas de genealogias sem os reis espanhóis divide a sala com uma reprodução da única série de pintura de castas peruana encomendada pelo vice-rei do Peru Manuel Amat y Juniet por volta de 1770. Esses pequenos exemplos, juntamente a um variado número de pinturas de caráter religioso, começam a compor o complexo e difuso conjunto classificado como pintura colonial hispano-americana definido por critérios, às vezes amplos, como período histórico, localização geográfica, a boa vontade e a necessidade de se criar elos em comum.

\footnotetext{
* Brenda Carlos de Andrade is Professor of Spanish and Latin American Literature at Universidade Federal Rural de Pernambuco (UFRPE). She holds a degree in English and Portuguese (UNICAP, 2004) and in Spanish and Portuguese (UFPE, 2004), an MA in Literary Theory (UFPE, 2007) and a PhD in Literary Theory (UFPE, 2014). Her PhD thesis focuses on Latin American nineteenth-century historical novels and the relation between literature and history during this period. Her current research deals with images of Colonial Latin America in both Literature and Arts. E-mail: brenda.carlosdeandrade@gmail.com
} 
Complementando esse quadro de começos descontínuos, apresento uma fotógrafa equatoriana contemporânea que usa da sobreposição de imagens antigas e de sua autoria, e um fotógrafo peruano, responsável pela construção de uma visão de mestiço.

Desse universo emanam diversas imagens: de uma menina que se repete em meio a fotos mais antigas de outras meninas (Chiriboga), um menino trabalhador (Chambi), bustos de imperadores incas produzidos no século XVII e XVIII, gravuras de um cotidiano de referência mestiça do começo do século XVII (Guamán Poma de Ayala), gravuras do descobrimento em livros de viagem do século XVI - um estranho e desigual conjunto que evoca como elemento principal essa tão conhecida e latente identidade latino-americana. Partindo de diferentes perspectivas para diferentes públicos, esse conjunto revela, além de uma diversidade óbvia, uma obsessão com a imagem ao longo da história do continente americano. Embora não se atendo a detalhes a respeito da situação muito anterior à chegada dos europeus, ainda assim pode-se afirmar uma presença preponderante do aspecto pictórico em várias culturas que se encontravam nesse território e uma continuidade bastante relevante na cultura colonial e seu desenrolar pós-emancipação. A forma de representação guardava, e guardou, mesmo no cadinho cultural que representou a sociedade colonial, aspectos próprios, maneiras particulares de representar. Enquadrá-las todas como arte poderia soar como um anacronismo ou uma idiossincrasia equivalente a chamar muitos textos pré-colombianos de literatura. No entanto, essa resulta ser, talvez, a solução mais lógica para se pensar esse conjunto.

A descontinuidade cronológica, espacial e de objetos foram os primeiros passos dados para essa reflexão, tal qual a ideia aparentemente "absurda" de precursor apresentada por Borges (1974). Há uma razão e uma conexão que se estabelecem entre essas formas de representar aparentemente desconexas que delineiam, como podemos observar, a continuidade entre as produções artísticas na América Latina compreendida como um conjunto passível de ser estudado sob essa categoria. A ordem aleatória converte-se num elemento fundamental para se entender os vários diálogos que podemos estabelecer entre essas obras. E todas essas ex- periências, ainda que artística e tecnicamente diferentes e distantes, parecem refletir uma estranha obsessão desenvolvida no continente americano pela imagem, pela literatura e por formas de fazer tanto a literatura como as imagens falarem de identidades locais com os mais variados e diferentes propósitos.

Observando a foto de Christiano Junior e os dois quadros de Eckhout abaixo, pode-se perceber essa continuidade nos traços, na maneira de representar os retratados. Um elemento comum é que, nos dois casos, a representação funciona não pela individualidade dos retratados, mas pelo que eles significam: decodificam iconograficamente elementos da cultura. Curiosamente, apesar dos séculos que separam as duas composições, ambas respondem a anseios de criar imagens para a terra brasileira. Não só a postura e expressão ligeiramente esvaziada das três figuras femininas as ligam, um estudo cuidadoso dos elementos que perpassam cada uma das criações proporciona uma visão sintética da pessoa representada.

No caso das imagens de Eckhout, a composição utiliza elementos da natureza brasileira que funcionam como uma síntese da terra. Na foto de Christiano Junior, a mulher encontra-se sozinha, despida de um cenário emblemático do país, as vestes e o cesto são os elementos suficientes para corroborar a ideia do que seria uma escrava. Esses elementos parecem acessar códigos e expectativas dos observadores de cada um dos períodos. Entretanto, o espaço temporal entre elas define diferenças fundamentais: a imagem do século XVII responderia ao impulso expresso pela divisa do reinado de Felipe II "conhecer melhor o espaço para governá-lo melhor", esquadrinhar geografia, fauna, flora e população constituía uma das formas mais sábias de manter o domínio. Na foto, apesar das semelhanças com os quadros, há um impulso ligeiramente diferente que parece obedecer às necessidades de seu próprio tempo. Esquadrinhar espaços e população, então, se tornava mais do que uma necessidade de conhecer e dominar o espaço: era uma forma de se dar a conhecer, dar a conhecer o país, impulso que se desenvolveu tanto pela tomada científica ao longo do XIX como pelo seu lado de repercussão pública com as Exposições Universais. 


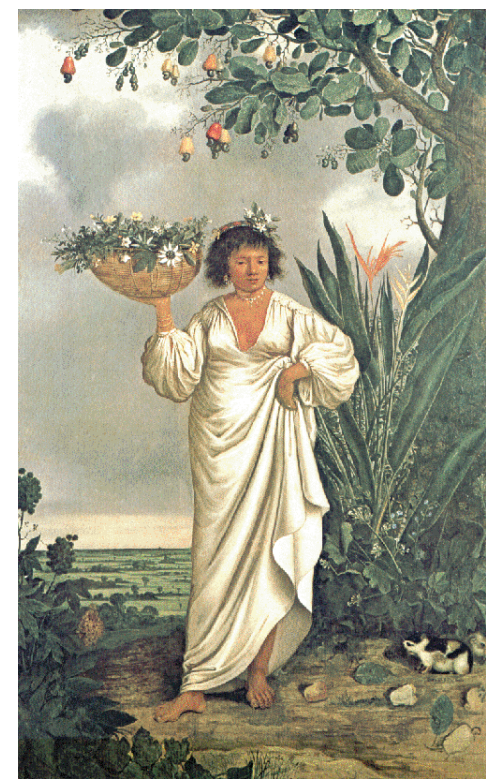

Mameluca, 1641, Albert Eckhout, Óleo sobre tela, Nationalmuseet (Copenhague, Dinamarca)

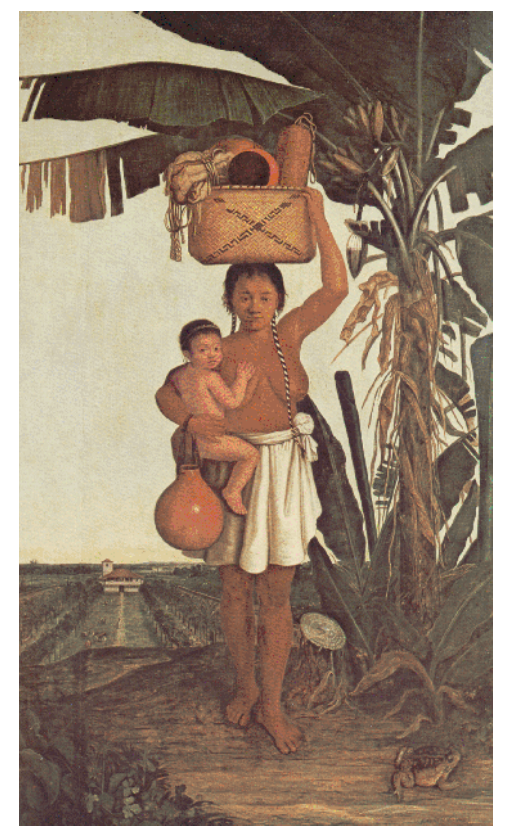

Tupinambá/Mulher Brasilian, 1641, Albert Eckhout, Óleo sobre tela, Nationalmuseet (Copenhague, Dinamarca)

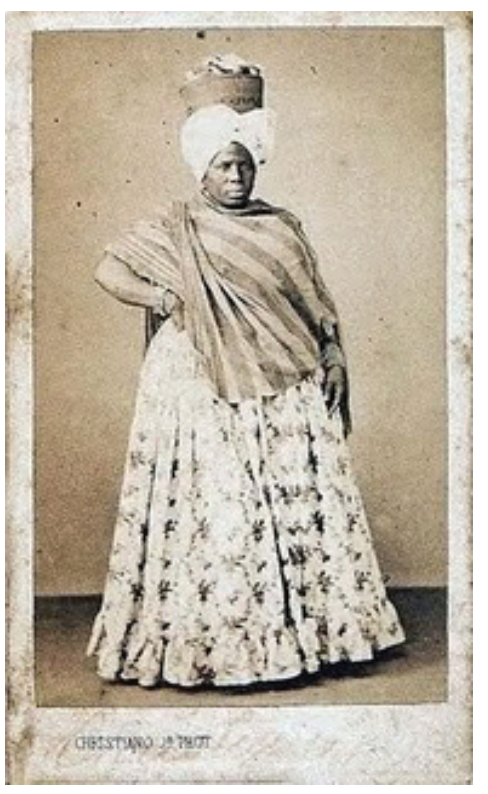

Retratos de Escrava, ca. 1865, Christiano Junior, Albúmen e cartão de visita, Museu Histórico Nacional (Rio de Janeiro, RJ)

Dos ecos/impulsos que falam os espaços da América, o domínio da(s) imagem(s) e sua "domesticação" talvez seja um dos mais relevantes. As inúmeras imagens que registraram as novas terras conquistadas nas mais diversas formas não pararam de se reproduzir, criando formas não só de registrar o cotidiano como também formas de ler e interpretar o visto. A marcação ou determinação cronológica, embora pese nas delimitações e amplificações de significados e interpretações, muitas vezes, é um aspecto atenuado, porque do presente se estabelecem diálogos infinitos com as imagens do passado, como uma serpente que morde a própria cauda.

\section{Imagens}

Com o influxo das navegações impulsiona-se uma larga produção de gravuras feitas ou pelos viajantes ou sob encomenda e baseadas nas narrativas dessas viagens. Essas gravuras visavam exemplificar visualmente o que era desconhecido e respondiam a um impulso de catalogação que estranhamente flerta tanto com elementos dos bestiários medievais quanto com um renovado impulso científico propulsado pelas ideias renascentistas e seus próprios reflexos com o descobrimento dessa parte do orbis terrarum. As gravuras desse momento, e até entradas algumas décadas do sé- 
culo XIX, flutuam entre o traço didático e a criação artística; muitas vezes, o aspecto didático domina. Elas funcionavam como prova, evidência, representação, materialização daquilo que o discurso sozinho acabaria por silenciar, mas também, como o discurso, eram formas de captar um/o outro através do olhar seguro e de categorias já conhecidas. As gravuras do livro de Clavijero e as produzidas por Humboldt, guardadas as devidas proporções, constituem parte dessa continuidade descontínua plasmada no discurso na e da América.

Num conjunto muito semelhante, a sociedade criolla desenvolve, além de uma larga e importante produção religiosa, uma série de pinturas que parecem manter o diálogo aberto com os tipos de gravuras mencionadas acima. As genealogias, as pinturas de castas e os retratos de caráter etnográfico supunham, além da representação, um elemento eminentemente didático criando uma imagem para que figurassem não só o quem são/somos, mas também o como. Nesse momento entre XVIII e XIX, ainda mais relevante se torna o diálogo e as misturas daqueles que compõem esse material porque o público deixa de ser exclusivamente europeu, assim como os artistas passam a se identificar com o retratado, em muitas ocasiões saindo do "eles são" dos primeiros períodos coloniais para o "nós somos", frente à Europa, o que anuncia talvez os desenvolvimentos das revoluções que levaram às Independências. Se é inegável que essas misturas se fizeram presentes desde os primeiros momentos da colonização com figuras emblemáticas como Guamán Poma de Ayala, Inca Garcilaso ou indígenas anônimos que se converteram nos grandes artesões e artistas das obras sacras na América Colonial, também não é irrelevante lembrar que a questão começa a ficar mais explícita a partir do XVIII. As duas genealogias, mencionadas na primeira parte, podem ser vistas como fortes exemplos de tomada de identidade a partir da negação de europeu. Esse tipo de pintura, baseada no modelo de genealogias das ordens religiosas e que esteve em voga ao longo do século XVIII, colocava em continuidade os imperadores incas e os reis espanhóis. Ao final desse mesmo século, surgem, entretanto, modelos em que a presença europeia é apagada e a herança inca de um passado histórico e glorioso passa a ser tomada do passado anterior à colonização.

Não se deve pensar que esse apagamento inicial venha de uma disposição separatista e amplamente compartilhada pela sociedade da época, mas não deixa de ser perceptível que parte desse sentimento, exposto pelos movimentos neoincas, é retomado nos discursos das elites criollas durante os processos de independência. Associar-se a esse passado nobre e anterior aos espanhóis se convertia numa maneira de legitimar a independência, evidenciando uma descontinuidade entre as duas histórias (inca e espanhola na América). Leopoldo Zea, em El pensamiento latinoamericano, chamou esse processo de negação não dialética do passado: negando a história e influência dos espanhóis nas Américas se buscava referência num passado anterior, teoricamente sem máculas, para que servisse de base para novos projetos de composição e identidades. Entre esses paradigmas de localização sempre viveu o continente americano e, consequentemente, suas formas artísticas.

Se observamos as imagens abaixo das duas genealogias, o primeiro elemento que diferencia as duas é a forma como são compostas: a primeira dispõe as figuras dos governantes em linhas que devem ser lidas de cima para baixo, enquanto a segunda, usando um modelo muito semelhante ao das ordens religiosas, faz uso da árvore que deve ser lida de baixo para cima. No entanto, em ambos, vemos a presença do casal mítico histórico Manco Capac I e Mama Huaco (Mama Ocllo, para algumas lendas) situados em uma posição que, simultaneamente, compõe a linha evolutiva, mas também uma espécie de moldura para o quadro - é o espaço que cabe aos fundadores. Manco Capac carrega uma representação do sol e sua esposa uma da lua, uma forma de relembrar as origens divinas dos dois e de toda a dinastia. Outro elemento que chama bastante a atenção é a ausência de traços particulares entre as figuras; não fosse pelas vestimentas, apetrechos e as legendas abaixo das imagens, a identificação seria quase impossível. Esse traço remete às duas tradições: a dos desenhos e pinturas pré-colombianas, cujas identificações pessoais costumavam se fazer exatamente por elementos externos, e a uma tradição retratista europeia que, em momentos alternados, tomou a frente nos mo- 
delos de representação. Castelnuovo, em seu livro sobre o retrato na sociedade italiana, e Brienen, em livro sobre Eckhout, comentam esse traço na pintura europeia. São pinturas mais representativas de tipos do que preocupadas com a definição de elementos que criem a individualidade de cada personagem, são figuras exemplares. O retratado interessa na exata medida do que ele representa para a sociedade, o lugar que ocupa nela.

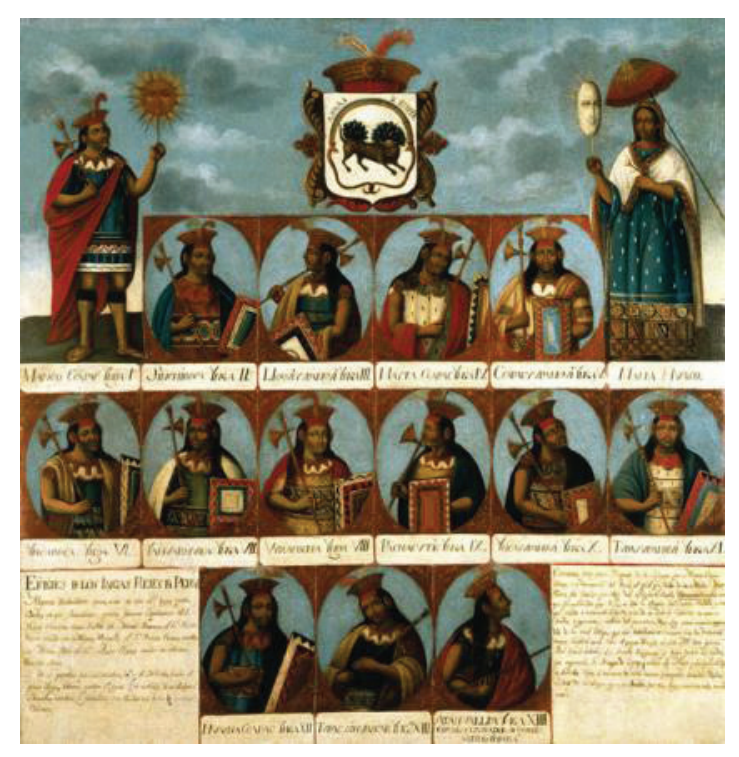

Genealogia dos Incas, fins do século XVIII e início do século XIX, Anônimo, Museu Pedro de Osma (Lima, Peru)

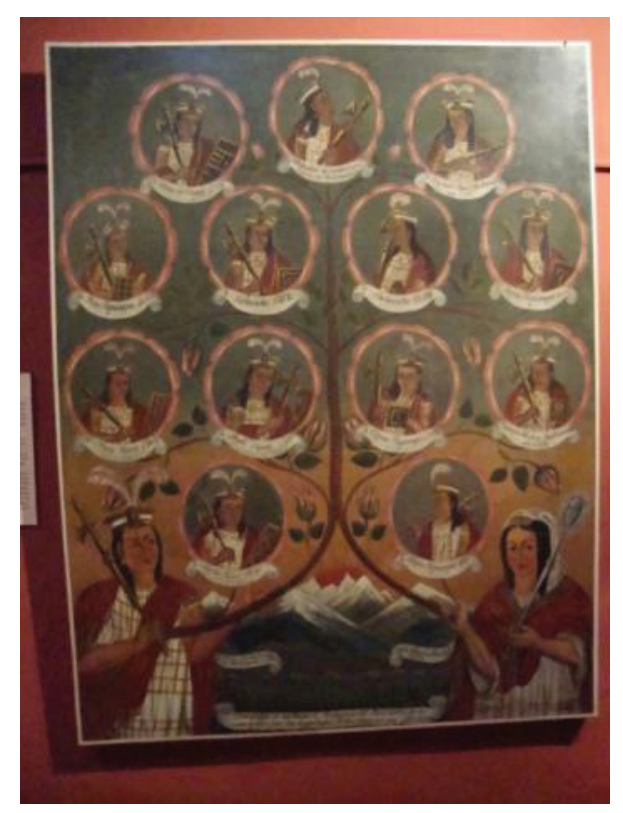

Genealogia dos Incas, século XVIII, Museu Nacional de Arqueologia, Antropologia e História (Lima, Peru)
Também nessa linha se enquadrariam as pinturas de castas que, combinando casais de diferentes "raças" e apresentando o fruto dessa união com sua devida classificação, se desenvolveram ao longo do século XVIII no território da Nova Espanha, à exceção, como mencionado, de uma série de autor desconhecido elaborada no Peru. Esses quadros apresentam formatos diferentes, desde uma tela única até um conjunto de telas. As classificações que trazem soam ligeiramente estranhas e parecem menos científicas e mais próximas de classificações medievais para o mundo desconhecido. Um dos elementos representativos desse tipo de pintura é a incorporação de traços do cotidiano ou através da inserção de pequenos objetos (um leque, um vaso) ao lado das figuras representadas ou como parte do segundo plano, pano de fundo das pinturas. Muitas vezes, as classes eram associadas às raças; aquelas consideradas mais altas tendem a ser representadas com elementos quase aristocráticos, já no caso das mais baixas um dos componentes do casal, ou todo ele, costuma ser representado como trabalhador em atividades não muito valorizadas.

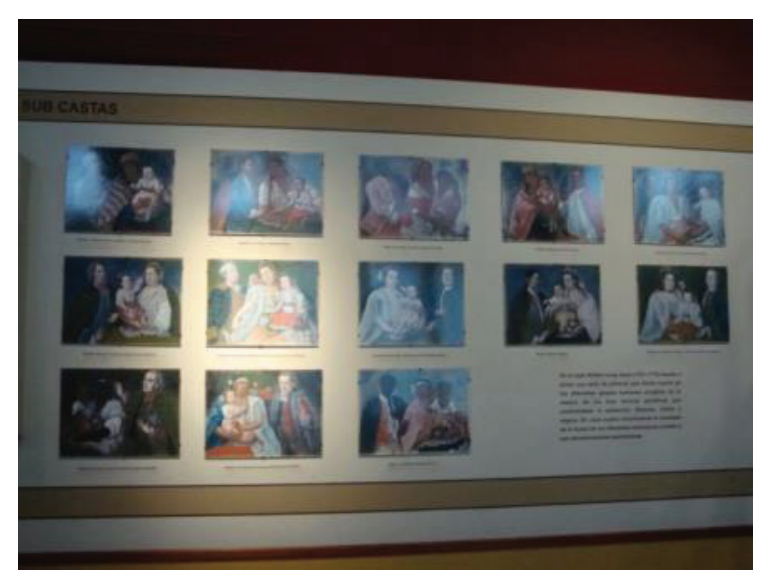

Pintura de Castas (parte do conjunto), ca. 1770, Anônimo, Museu de Arqueologia, Antropologia e História (Lima, Peru) 


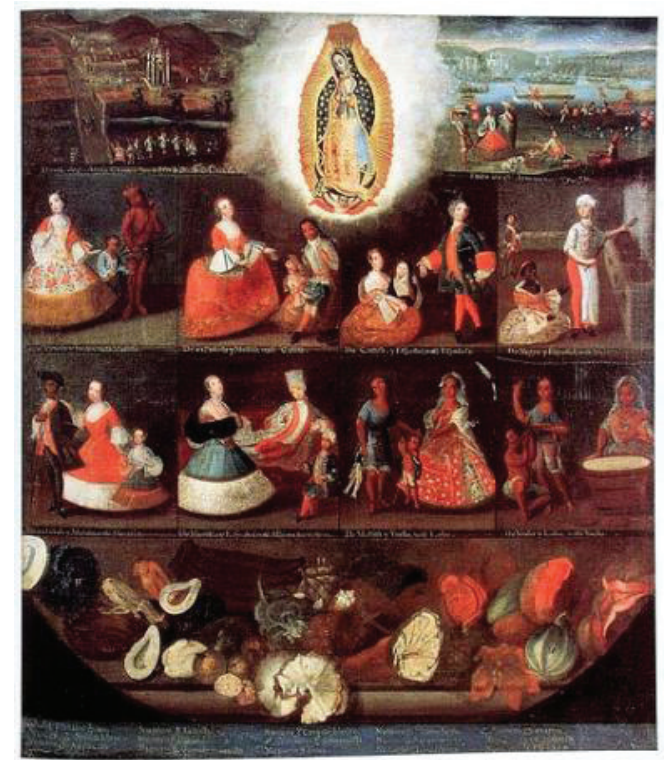

Pintura de castas y Virgen de Guadalupe, 1750, Luis de Mena, Museo de América (Madri, Espanha)

Com a descoberta e desenvolvimento de processos de captação de imagem (heliografias, daguerreótipo, calótipos, enfim, a fotografia), emerge um novo suporte para apreensão dessas realidades, que, apesar de seu caráter experimental e amador, foi difundido rapidamente pelo território americano, apropriando-se dessas novas técnicas como se nele elas houvessem sido descobertas. Vale mencionar o francês Hercule Florence cujas pesquisas na área de fotografia, desenvolvidas no Brasil, foram contemporâneas às descobertas na Europa, de acordo com as pesquisas de Boris Kossoy. Uma nova moda e um novo modelo de desenho se infiltravam entre as artes de representar e ocupariam um lugar privilegiado a partir de então. Seria de esperar talvez uma mudança no modo de representar?

A descoberta de meios para reproduzir imagens do mundo tal qual olhos humanos poderiam perceber abriu as portas para uma nova forma de representar e construir imagens. A fotografia e seus antecessores, assim, pareciam destinados a serem vistos como uma forma de captar uma imagem do real, que indica uma relação contínua direta com o objeto representado. No entanto, a experiência com essa nova arte (técnica) acaba por desmentir essa ideia de continuidade e afirmar a certeza de mediação entre o real e o real representado. ${ }^{1}$ A mediação através do olhar do fotógrafo, filtrando, a partir de sua experiência, expectativas de leituras do mundo, também pode surgir da relação do fotografado com a pose e, por último, com o olhar posterior de um espectador que observa a foto muito tempo depois de ela ter sido tomada. No século XIX, na produção de retratos, evidencia-se essa "artificialidade" da percepção do outro pela indumentária, cenário e objetos utilizados para representar os diferentes personagens a serem fotografados e as indicações que davam os fotógrafos àqueles que seriam fotografados. Esse processo faz com que as fotos sejam não apenas uma cópia de um objeto ou pessoa originais; elas trazem, em si, expectativas de como deveriam ser vistos esses objetos e essas pessoas.

Os caminhos que levam às fotografias se bifurcam em veredas de ambiguidades e contradições em sua própria natureza; assim pensam e sentem muitos dos que se confrontam com o seu estudo. As fotos estabelecem uma espécie de ponte entre vários binômios que perseguem a arte: amadores e profissionais; arte e comércio; espaço íntimo e espaço público (Quando algo deixa de ser de interesse puramente pessoal e ganha status de arte ou de estético? Quando o pessoal pode ser elevado à categoria de arte?). O percurso desse trabalho está marcado por um intrincado caminho pontuado, em seu começo, por uma nota íntima, um fragmento de memória, em forma de quadro herdado: Campesinos Indígenas en el Juzgado (Chambi). A foto põe o observador em uma incômoda situação, como em um vazio entre o belo e o ligeiramente perturbador. Olhares nos seguem por todos os pontos a partir do qual observamos, um grupo de camponeses um tanto estranho parece perturbar a ordem supostamente alentadora das fotos antigas. Algo parece escapar cada vez que observamos a foto de Chambi. Os camponeses, à primeira vista, podem ser tomados por representantes de classes oprimidas e marginalizadas, herdeiros dos incas. O grupo sentado em um banco de um tribunal parece apresentar-se como réus; no entanto, num segundo momento, seus olhares nos prendem. Eles esquadrinham o espectador, o acusam, olham-no como se olhassem a alma, como se pudessem descobrir o que há de culpado em cada um, eles convidam o espectador a participar de uma gama variada de sentimentos que costumam figurar na história dos povos americanos: submissão, desprezo, humildade, medo, rancor, dor. Sentimentos tão humanos, 
mas que estão, neste caso, transfigurados pelos traços indígenas das caras e das roupas típicas que gritam em desacordo com a decoração do tribunal e dos outros tipos humanos que estão ao redor deles. Há qualquer coisa de familiar e estranho nessa espécie de pintura de ruínas, ruínas de um passado imperial inca, genealogia rota de expressões que se perdem e se encontram entre os tempos.

Dessa impressão, nasceu a curiosidade que leva a um labirinto de imagens entre passado e presente, comentado anteriormente, que supõe querer dizer algo ou diz à sua própria revelia. A partir desse ponto, pretendo analisar uma seleção de fotografias de quatro diferentes fotógrafos, de espaços e tempos distintos dentro da América Latina, e como se desenvolvem a partir delas algumas possibilidades de se interpretar e construir uma memória da representação de identidades. Se as identidades na América Latina parecem imbuir-se de caracteres diversos que evidenciam os processos deslizantes e mutáveis da memória, as fotos de Christiano Junior, Marc Ferrez, Martín Chambi e Lucía Chiriboga trazem essas características desestruturadoras expostas através de processos técnicos e plásticos diferentes, que, no entanto, se desenvolvem próximos da concepção de Barthes ${ }^{2}$ de punctum. Seriam como formas de apreender a identidade, como tentativas fracassadas de memória, mas que, fracassando, alcançam êxito ao captar em fragmentos o que só pode ser lido por fragmentos. Quatro fotógrafos, quatro países, três tempos: a linha tramada que une esse pequeno levantamento numérico, além da visão interpretativa do observador, emerge de uma tentativa de captar identidades específicas de determinados povos. $\mathrm{O}$ impulso de cada um desses fotógrafos difere, mas uma unidade começa a surgir dessa diferença, como se a trama invisível dos trejeitos se repetisse na foto, seja para imitar claramente uma imagem, seja uma expressão involuntária da repetição, dialogando com seus passados e representações passadas. Delas emana um discurso aparentemente anterior do como sou visto e como quero que me vejam, por parte dos fotografados, e do como captar e como eu vejo esse diferente, que está diante de mim.

Os retratos trazem na sua própria natureza uma ambiguidade de origem, desde as pinturas até seu mo- mento mais popularizado com a fotografia. Antes das técnicas fotográficas, era comum que os pintores "retocassem" os retratados para esconder-lhes os defeitos, atribuir-lhes mais dignidade ou simplesmente para que a imagem do retratado respondesse a um modelo pré-estabelecido da forma de retratar. ${ }^{3}$ No período áureo de difusão fotográfica, tomando lugar das antigas pinturas de retratos, dois tipos de fotos se fizeram bastante presentes como forma de expressar e captar uma imagem, ao mesmo tempo, desejada e real dos modelos: retratos individuais e de família. Como estilo e forma, eram basicamente usados em fotos comerciais e, em seu princípio, traziam certa marca social, transformandose num símbolo de status burguês. Aquele que possuía uma foto de si mesmo era alguém disposto a posar e pagar pelo produto. No caso da seleção feita, os fotografados pertencem a outra categoria, têm suas imagens tomadas não por interesse próprio, mas por interesse do profissional, seja esse estético ou etnográfico. Também representam uma continuidade descontínua em relação a esses dois modelos de retratos, os repetem de forma não-convencional.

José Christiano de Freitas Henriques Junior, mais conhecido simplesmente por Christiano Jr, nasce em Açores em 1832 e muda-se para o Brasil aos 22 anos. Desenvolve sua carreira como fotógrafo entre o Rio de Janeiro (primeira parte) e Buenos Aires (segunda parte). Suas atividades como profissional da fotografia são tão diversificadas como as de qualquer outro no período: comercializa retratos, reproduz gravuras, faz fotos de paisagens para estereoscópios, carte-de-visite de vários personagens importantes da época. No entanto, as séries de fotos de escravos simulando suas profissões feitas em estúdio no Rio de Janeiro, e de trabalhadores, em alguns casos já em locações externas, em Buenos Aires, formam talvez o conjunto de imagens mais curioso e importante de sua obra. Elementos das pinturas etnográficas e das gravuras reaparecem nessas fotos altamente estudadas. Cada uma delas, como a da escrava comentada anteriormente, apresenta poses elaboradas em que pequenos elementos se ajustam para significados mais amplos; algo nelas também indica uma espécie de diálogo entre a as pinturas anteriores. É como se as fotos no século XIX tomassem certas poses e trejeitos 
para relocar um arsenal e utilizá-lo numa atividade técnico-artística recém-descoberta e ainda reticente ante seu espaço na sociedade.

$\mathrm{Na}$ foto a seguir, por exemplo, vê-se um homem e um menino, ambos quase em mangas de camisa e descalços, uma curiosa touca ou turbante envolvendo suas cabeças. O homem se posiciona de perfil e a criança também, mas na direção oposta e de cabeça baixa, parece levar um tapa dele. A mão direita do menino toma a mão livre do homem num estranho gesto que pode, corroborando a ideia da briga, ser uma tentativa de impedir seu ataque, como também pode ser, num sentido contrário, quase um gesto de carinho. A contradição da imagem se explicaria por se tratar, segundo algumas fontes, da primeira imagem fotográfica de um jogo de capoeira, o caráter estático da imagem, resultado das técnicas conhecidas no período, em quase nada se assemelha ao dinamismo que instantaneamente vem à mente quando se pensa nesse tipo de jogo. Ao contrário, esse lado estático e estudado de uma cena de aparente violência lembra um dos quadros de casta que compõem a série de Andrés de Islas. O simulacro da briga, a posição dos corpos, essa tentativa de representar um aspecto dinâmico parece confluir para aspectos semelhantes, ao menos na superfície das obras. O cenário cheio e bem localizado na cozinha da casa presente na pintura de Islas se diferencia do estúdio limpo em que foi tomada a foto.

Assim como na pintura de Eckhout, essa do século XVIII traz o impulso de catalogação da vida cotidiana a partir não somente do tema principal a ser retratado, mas também dos elementos que rodeiam esse tema como se eles conformassem um todo mais facilmente traduzível e, portanto, mais significativo em sua compreensão detalhada. Segundo Efraín Castro Morales, ${ }^{4}$ em princípios do século XX muito se debateu a respeito do traço prático e funcional dessas pinturas tomadas como documentos gráficos. Atualmente, acredita-se que tal tipo de pintura nunca tenha realmente se aproximado de uma aplicação prática e que teria sido elaborada para suprir uma espécie de curiosidade peninsular sobre a sociedade americana colonial como tipos físicos, indumentária, ofícios, misturas raciais baseados em classificações eruditas que, de fato, nunca haviam sido empregadas pela sociedade colonial. Nesse aspecto, a foto de Christiano Junior se assemelha à pintura de Andrés de Islas e seus contemporâneos, pois respondem muitas vezes a anseios externos a respeito de informações sobre o país. Os meios de divulgação dessas fotos (cartões postais, álbuns de vistas e costumes e, às vezes, nas famosas exposições do século XIX) tendem a confirmar isso.

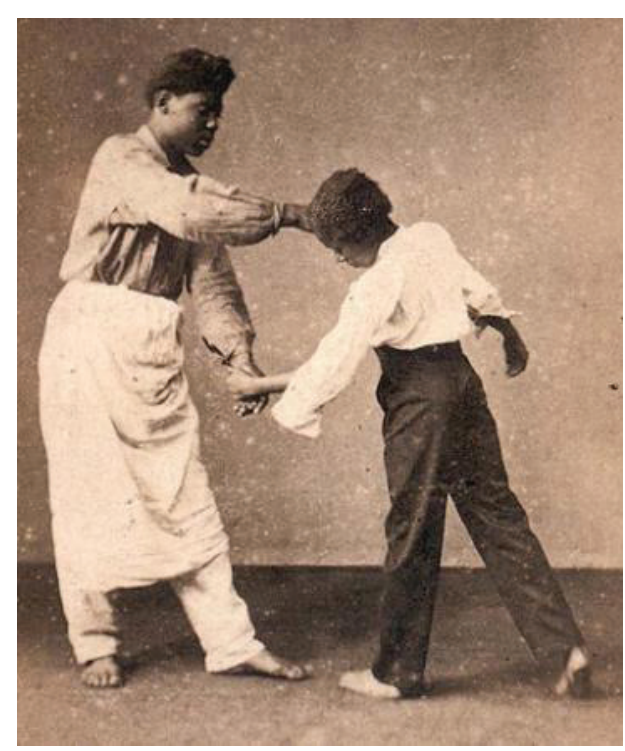

Capoeira, 1864-1866, Christiano Junior

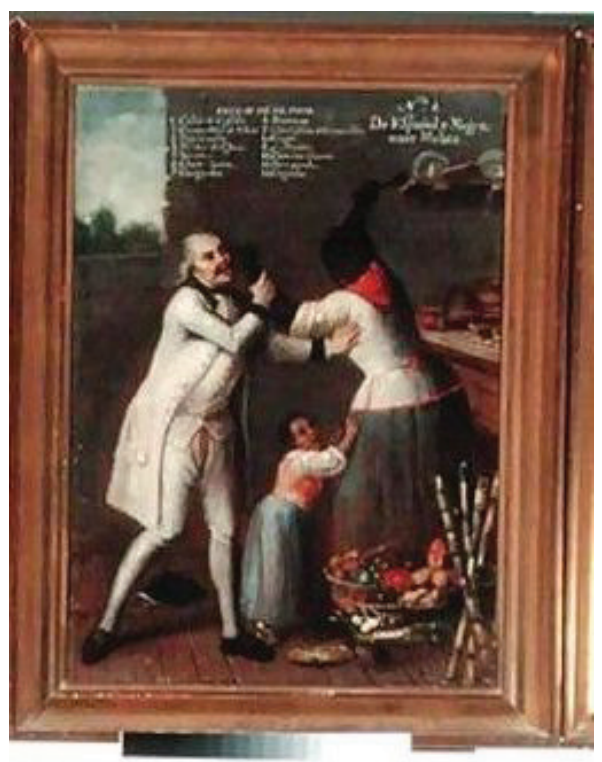

De español y negra: mulata, século XVIII, Andrés de Islas, Museo de América (Madri, Espanha)

No caso da capoeira, como na sequência de fotos de ofícios que se observa a seguir, a diferença mais visível se impõe por uma estética mais minimalista na 
representação dos elementos no entorno do tema principal. Nesse conjunto, o estúdio encontra-se vazio, a representação das profissões se faz a partir das roupas e, principalmente, dos instrumentos de trabalho: na primeira, carregadores com caixas e uma cadeira; na segunda, um homem que parece um leiteiro carregando um recipiente cilíndrico; e na terceira um grupo de três negros com balaios, possivelmente artesãos. $\mathrm{Na}$ foto seguinte, encontra-se um tipo semelhante de composição, já em seu estúdio em Buenos Aires: três meninos vendedores de jornais posam estudadamente, guiados para tal postura. O primeiro em pé com os jornais distribuídos cuidadosamente aos seus pés; do lado esquerdo, vê-se outro sentado que folheia os jornais como se contasse e, do direito, um terceiro menino, de joelhos no chão, exibe um jornal como quem tenta mostrar seu título. A repetição nos modos de representar é tão evidente que, alguns anos depois, Marc Ferrez fará retratos de vendedores de jornais em poses semelhantes às das fotos de Christiano Junior. Esses trabalhos constituem uma espécie de catalogação das variedades de ofícios da época; serviam tanto como figuras curiosas em cartões postais como compunham obras como elemento informativo. Nos famosos álbuns de vistas e costumes, entravam como representações iconográficas da categoria de costumes.

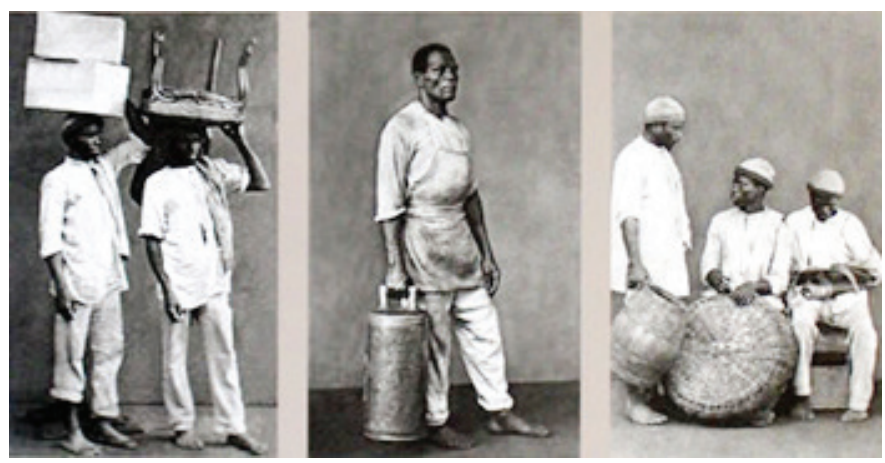

Escravos, século XIX, Christiano Junior, Museu Histórico Nacional (Rio de Janeiro, Brasil)

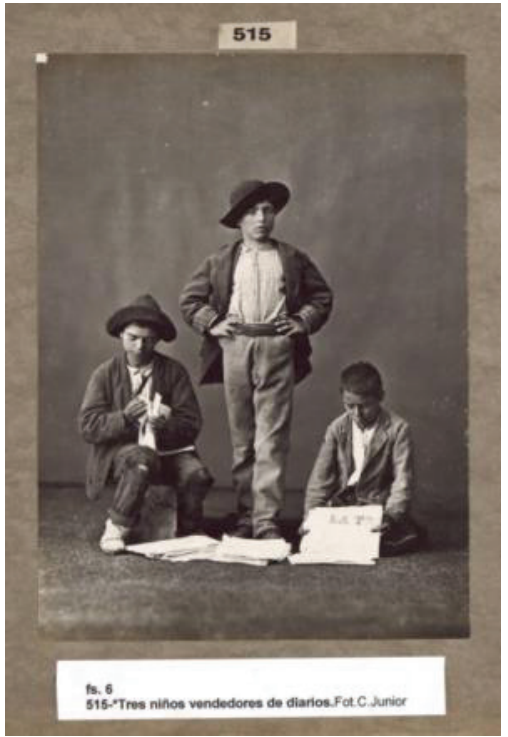

Tres niños vendedores de diarios, segunda metade do século XIX, Christiano Junior, Archivo General de la Nación Dpto. Fotográficos (Buenos Aires, Argentina)

Uma sutil mudança ocorre com as fotos "Verdurero y panadero" e "Aguatero", esta última atribuída a Alejandro Witcomb. ${ }^{5}$ As tomadas saem do espaço fechado do estúdio e passam a incorporar o espaço externo, criando um entorno cheio, semelhante às pinturas vistas acima. Ao incorporar esse entorno, o artista cria uma leve diferença; não são mais as simples representações ilustrativas do ofício, mas os trabalhadores exercendo sua função. A natureza forma um conjunto que se presta para uma localização espacial para essas obras. Os primeiros podem ser tomados como verbetes de dicionários ilustrados, enquanto os segundos levam mais à ação, dentro dos limites das técnicas fotográficas do período. Evidentemente, essas tomadas externas não foram fruto exclusivo do desejo de uma mudança estética, mas também de uma mudança técnica. Os primeiros recursos para captar a imagem requeriam um tempo de exposição prolongado e modelos imóveis durante o processo, algo que só poderia ser feito no ambiente controlado do estúdio fotográfico. Por essa característica, muitos estudiosos comparam a produção das primeiras fotografias a processos de retrato pintado. 


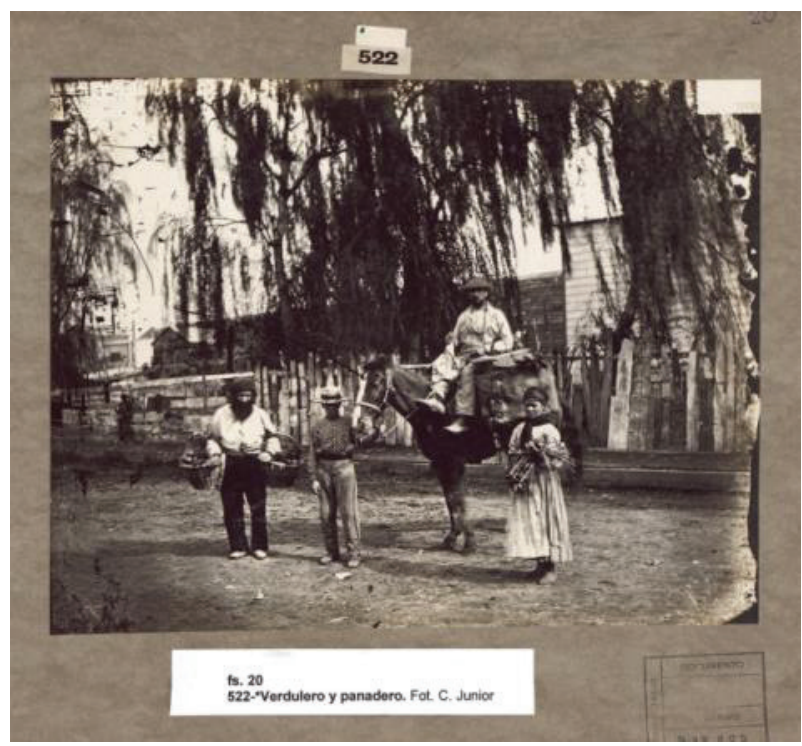

Verdurero y panadero, segunda metade do século XIX, Christiano Junior, Archivo General de la Nación Dpto. Fotográficos (Buenos Aires, Argentina)

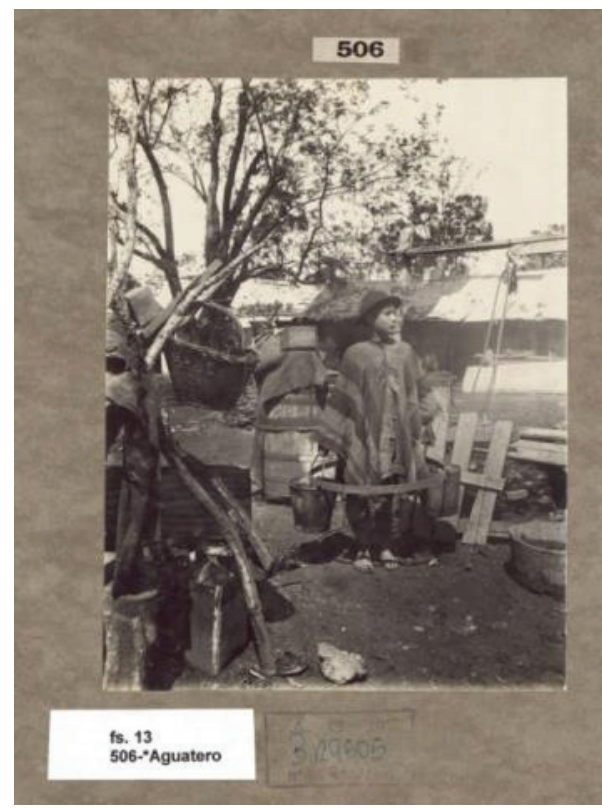

Aguatero, segunda metade do século XIX, Alejandro Witcomb, Archivo General de la Nación Dpto. Fotográficos (Buenos Aires, Argentina)

O artista/técnico Marc Ferrez, nascido no Rio de Janeiro em 1843 de pais franceses, atua mais ou menos no mesmo período. Após ficar órfão, é mandado para estudar na França de onde volta adolescente para empregar-se na Casa Leuzinger, do fotógrafo suíço George Leuzinger. Abre seu primeiro estúdio em 1867, que será destruído por um incêndio em 1873. Logo, volta a abrir um novo estúdio no centro do Rio de Janeiro. Tornase bastante conhecido por suas fotos panorâmicas e de aspectos da cidade, desde paisagens naturais a aspectos arquitetônicos e de elementos que capturam o progresso nas cidades.

Dentre essas composições da cidade, encontramse várias fotos semelhantes às dos trabalhadores de Christiano Junior e de Alejandro Witcomb, tanto com tomadas internas como externas. Na foto do amolador, vê-se um trabalhador simulando o uso da máquina e segurando uma tesoura aberta, o fundo com um pano branco impede qualquer identificação do local, novamente é como se a foto remetesse a um conceito visual de amolador. Na foto seguinte, têm-se vendedoras no mercado; não se tem uma visão ampla do mercado, mas o acúmulo de balaios e tabuleiros cheios de frutas traz essa ideia.

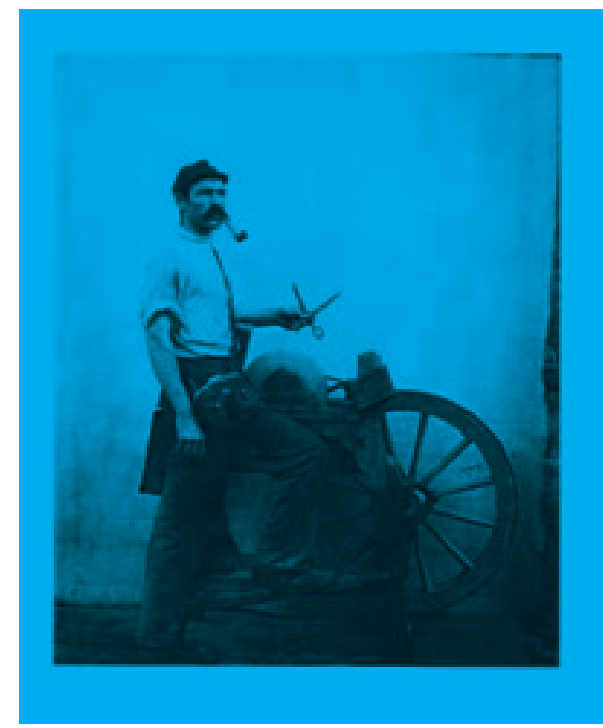

Amolador, c. 1899, Marc Ferrez, Instituto Moreira Salles ${ }^{6}$

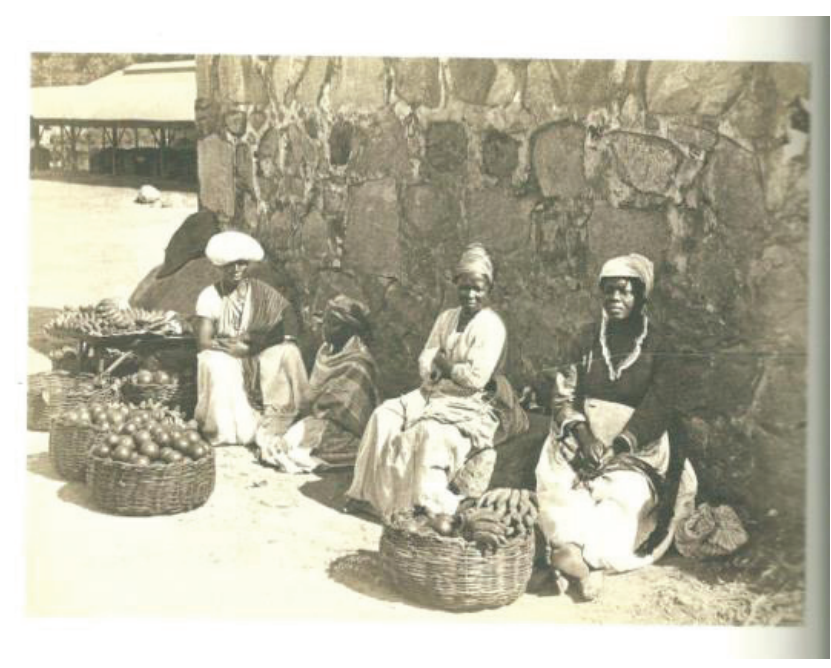

Mulheres no mercado, c. 1875, Marc Ferrez, Instituto Moreira Salles 
Uma produção menos extensa e mais desconhecida são os acervos de fotos de índios, produzidos muitos deles quando em trabalho para a Comissão Geológica. Embora o retrato não tenha sido seu forte, seus retratos dos indígenas de Mato Grosso são interessantes, pois repetem a fórmula aplicada aos retratos comerciais, de família e individual. A foto tirada em estúdio dos índios Bororo do Mato Grosso poderia ser uma exemplar foto de família não fosse o estranho dos "personagens" que integram a obra. ${ }^{7}$ Tomada em estúdio, possivelmente em 1880, nela observa-se um grupo de 11 índios dispostos em duas filas, uma por trás em pé, e uma segunda sentada, à frente. De longe, os tons sépia e os cabelos mais longos desses indígenas poderiam deixar uma ligeira dúvida sobre a composição dessa família, poder-se-iam notar membros de ambos os sexos numa estrutura hierárquica que prioriza o chefe da família sentado no centro, num banco diferente dos outros, que se encontram no chão. A essência de familiaridade da foto que o olhar afastado capta, no entanto, vai ser desmentida pelo olhar próximo e atento: essa estranha família não só é composta exclusivamente por homens como todos eles apresentam-se nus, ostensiva e displicentemente. Quase todos levam uma flecha nas mãos e uma curiosa faixa que lhes cruza o peito, alça de uma bolsa de palha que todos carregam atrás, exceto o chefe, que a leva ao seu lado. As duas figuras centrais da fila que se encontram em pé levam suas mãos ao ombro desse estranho chefe de família, gesto que nas fotos de família parecia indicar respeito e intimidade. ${ }^{8}$ Como representante e chefe, a figura do meio também traz uma expressão mais séria e concentrada, como deveriam ser as expressões ensaiadas para que se pudessem tomar as fotos, quando as poses eram ainda um pouco demoradas. Outro elemento que aponta um diferencial de distinção é a casaca utilizada por ele, também podendo representar uma espécie de mímica daquilo que se esperava de um representante ou chefe de família, uma roupa ocidental que sugere respeito, poder e autoridade. Entre os índios do grupo, cada um traz um tipo de olhar diferente, variando entre zombeteiro, escrutinador, desafiador, curioso.

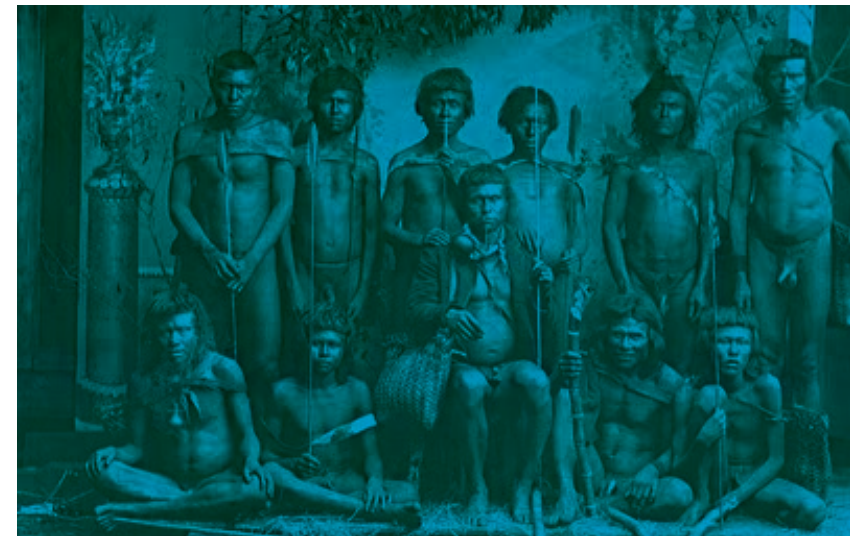

Índios Bororo, c. 1880, Marc Ferrez, Instituto Moreira Salles

Um elemento que salta aos olhos é o cenário por trás do estúdio, uma pintura de natureza exuberante levemente artificial e que se torna ainda mais artificial se forem consideradas as partes de estúdio que aparecem nos dois lados da foto, decretando explicitamente o fim da pintura, da fantasia. Se foi mero acidente ou foi intencional é difícil afirmar, porém parece que Marc Ferrez tentou uma postura realista, uma vez que o chão aparece coberto de palha com pedaços de cana de açúcar. A presença da cana não deixa de ser algo idiossincrático já que ela não pertencia à cultura indígena, mas, de certa forma, representava a imagem que se tinha do Brasil, um de seus aspectos naturais, como os nativos e a natureza exuberante. Essa afirmação não quer, entretanto, vincular uma ideia preconceituosa de Ferrez em relação a seus fotografados, simplesmente deixa claro uma espécie de imagem preconcebida, tanto na sua forma, retrato de família se enquadrando na representação do grupo indígena, como na simbologia das suas imagens e como elas são percebidas pela ideia que se tem de Brasil. Assim, o que se vê quando se olha para esse grupo também faz parte do que se espera ver ao olhar um grupo de indígenas no século XIX. Um fato curioso com relação à paisagem é que a artificialidade do cenário remete imediatamente ao realismo do outro cenário criado por Joaquim Insley Pacheco para retratar, também em estúdio, o imperador D. Pedro II (1883). Nesse caso, plantas de verdade foram dispostas para a foto do monarca; aqui a presença real de vegetação nativa cria uma espécie de continuidade de transferência com a imagem do imperador, que, pela proximidade, é associado à imagem de "exótico" do Brasil que vinha sendo divulgada e explorada, no século XIX, como ma- 
téria de interesses e expedições científicas. A vegetação real comprova a presença do exótico junto à imagem civilizada de D. Pedro; já na foto dos índios Bororo não é necessário nenhum suplemento para esse grupo.

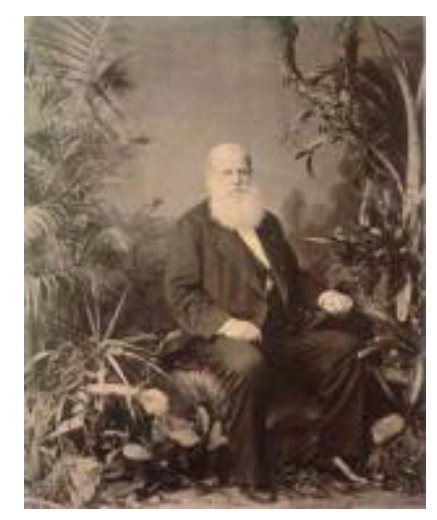

Retrato de D. Pedro II, 1883, Joaquim Insley Pacheco, Biblioteca Nacional (Rio de Janeiro, Brasil) ${ }^{9}$

Como participante da Comissão Geológica, o fotógrafo fez uma viagem para a Bahia da qual resultou numa série de fotos dos índios Botocudo. Muitas delas possuem um caráter científico explícito de catalogação. Um tipo de retrato de indígenas produzidos por Marc Ferrez nessa viagem são as fotos científico-etnográficas em que índios posam de lado e de frente, ao lado de uma espécie de fita métrica. A fita serve para medir e comparar as proporções dos indígenas em relação a outros povos. A herança da frenologia e da fisiognomia, que ainda estavam passando por um período áureo, justificava cientificamente certas classificações da espécie humana.

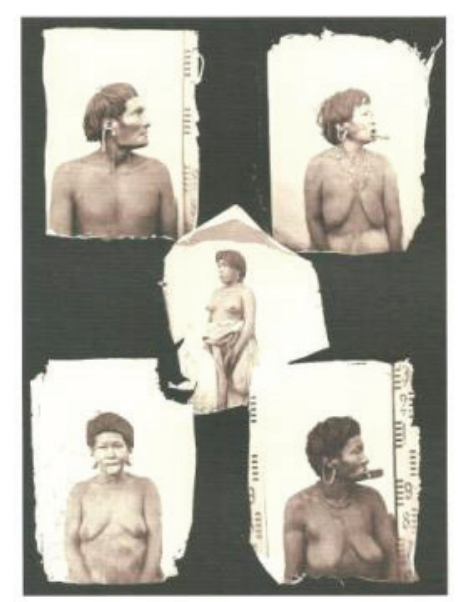

Índios Botocudo no sul da Bahia, 1875, Marc Ferrez, Instituto Moreira Salles
Em 1882, Ferrez viaja para as províncias de São Paulo e Minas Gerais a serviço da Estrada de Ferro D. Pedro II como fotógrafo encarregado de registrar o andamento das obras. Nesse período, produz uma série de fotos de indígenas e seus apetrechos, muitas vezes em estúdio improvisado. ${ }^{10} \mathrm{~A}$ foto do menino índio conhecida como "Indiens de Mato Grosso" foi possivelmente tirada durante esse ano. Nela vê-se um menino índio trajado de acordo com o que se acreditavam ser as indumentárias típicas dos índios. Em contraste com a foto anterior, em que os índios estavam praticamente destituídos de acessórios, contando unicamente com alguns de seus instrumentos de trabalho, o que se vê nesse menino é uma riqueza de detalhes: enfeites de penas, colares, pulseiras, flechas, até a pele de uma onça estendida no chão impõe um halo de nobreza à figura do menino índio. O retrato aqui toma o porte sério e nobre que se exigia dos retratados no séc. XIX. A própria expressão do menino é compenetrada e estudada, aparentemente seguindo orientações do fotógrafo, como costumava acontecer. Esse ar sério e compenetrado realça algo do exótico esperado nesse tipo de retrato; é como um nobre representante dos nativos da terra, uma espécie de imagem de um possível Peri. Aqui, como na foto do imperador tirada por Pacheco, o excesso de apetrechos ajuda a tornar a cena mais realista e mais interessante, tanto pelo apelo à expectativa do público comum como em relação à expectativa de um público mais especializado, preocupado com os aspectos etnográficos e científicos, que começavam a despontar de forma incisiva ao longo desse século. É, entretanto, uma imagem de um passado quase apagado, está mais perto do modelo de indígena que "fundou" a nação do que realmente próxima da imagem dos indígenas como viviam naquele tempo. É um caso em que o cuidado e o esforço do fotógrafo se voltam para copiar uma imagem mais simbólica que realista, mais um modelo de passado que imagem do presente. 


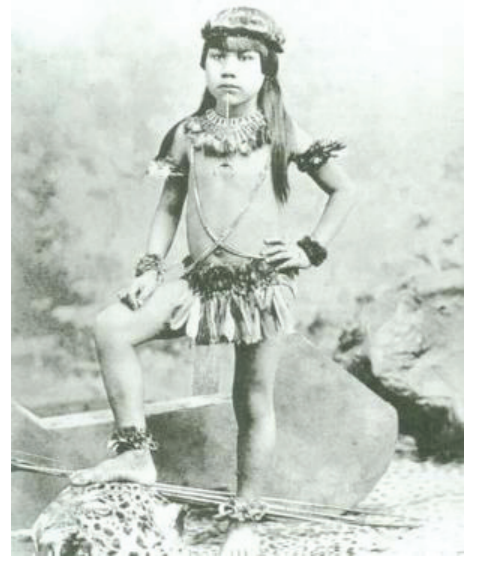

Indiens de Mato Grosso, c. 1882, Marc Ferrez, Instituto Moreira Salles ${ }^{11}$

Martín Chambi vive a transição do século XIX para o XX. Nascido em Coaza, se estabeleceu em Cuzco com um estúdio fotográfico na década de 1920, produzindo nas três décadas seguintes uma obra de temática variada que, entretanto, costuma-se dividir em quatro grupos distintos $^{12}$ : retratos comerciais, paisagens e vistas arqueológicas, documentação etnográfica e autorretratos. Estes quatro podem ser reduzidos a dois grandes grupos, obras artísticas (os três últimos) e obras comerciais (o primeiro grupo). Esta divisão clara entre duas produções de categorias distintas se percebe no material empregado para a tomada das fotos, para o trabalho comercial negativo $10 \times 15 \mathrm{~cm}$ e para trabalhos artísticos negativos de $12 \times 18 \mathrm{~cm}$ ou $18 \times 24 \mathrm{~cm}$, o que facilitava a ampliação. Essas fotos teriam mais qualidade técnica, já que o negativo maior possibilita uma ampliação em grandes dimensões, o que demonstra claramente a tomada de posição do artista em relação a sua obra: ele realmente se vê mais próximo do artístico.

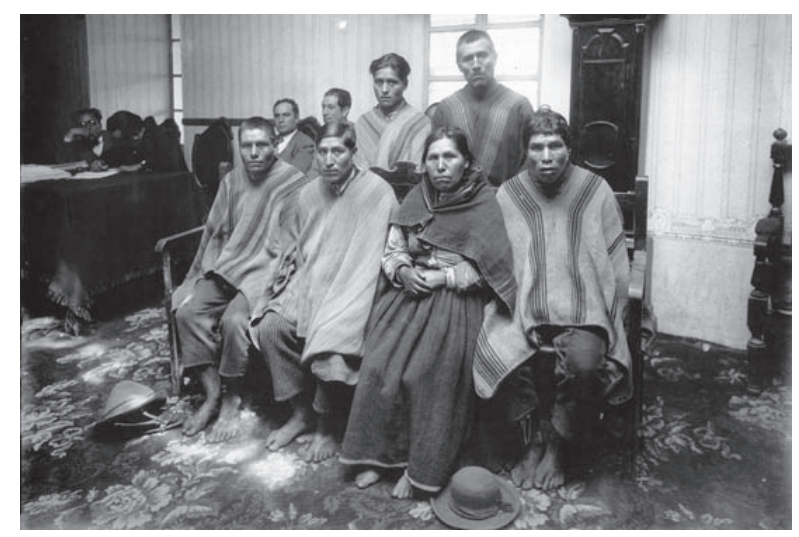

Campesinos en el Juzgado, 1929, Martín Chambi ${ }^{13}$
Fotos como a do "Organista indígena", do "Gigante indígena" e dos "Campesinos indígenas en el juzgado" jogam com planos distintos de construção de tempos e culturas diferentes. A imagem mais exótica que se vê em Ferrez muda em Chambi não só pela localização no tempo, mas também pela diferença histórica com relação à assimilação e presença indígena nas cidades. Em "Campesinos...", as vestimentas indígenas, as roupas, marcas da homogeneização do Ocidente entre os que não estão no grupo principal, os móveis coloniais, contrastam com o grupo de camponeses e, sobretudo, com o olhar altivo da senhora que se encontra no meio deles. Outro detalhe interessante é o homem de pé à direita; seus traços não se assemelham ao dos outros indígenas, seria alguém mais facilmente associável a uma origem caucasiana: seria um mestiço? Assim como a foto de Ferrez, mostrada acima, a disposição também a coloca entre os modelos de uma foto de família.

Outra vez, no entanto, o engano seria fruto de um olhar desatento, distante, a proximidade revela a ausência de um elemento importante nesse tipo de foto: a figura paterna. Em lugar de um cômodo familiar, um tribunal repleto de homens diferentes e que parecem indiferentes ao que se passa. O olhar severo da "mãe" contrasta com a forma um tanto perdida dos outros a seu redor. Nos olhares apáticos dos homens, pode-se ler medo, receio, incompreensão, exceto pelo homem que está atrás da mulher, que não parece indígena. Nele, o sentimento que domina é algo entre rancor e ódio. Um elemento curioso parece ser o homem do lado esquerdo, que observa a cena fotográfica como um espectador dentro da própria cena. A ordem e a disposição, que remetem a uma foto formal de família, são desmentidas pela proximidade do olhar que nos confronta com um estranho grupo, num lugar um tanto peculiar para esse tipo de foto. 


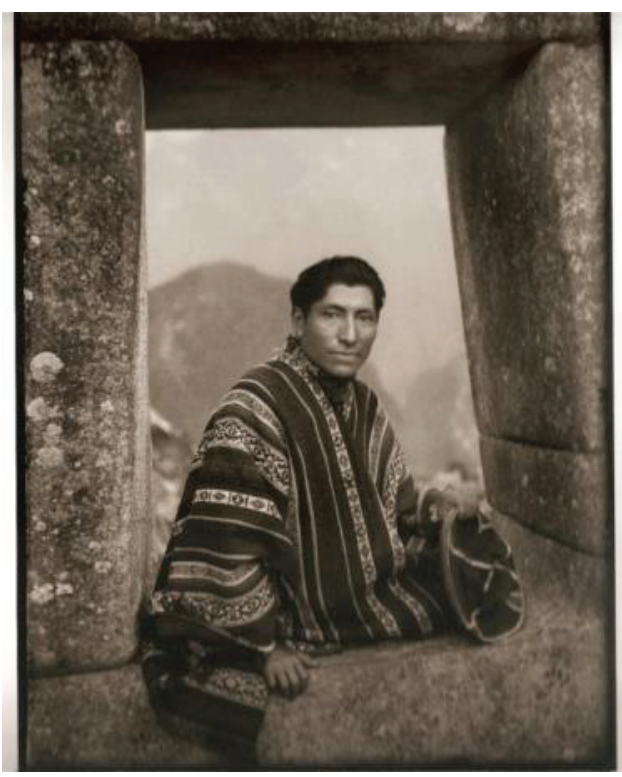

Autorretrato, Martín Chambi

Essa segunda foto de Chambi compõe, curiosamente, sua série de autorretratos, em geral tomados em estúdio, com ele usando paletó preto. À primeira vista, o que se vê é alguém de traços marcadamente indígenas com trajes típicos. O cenário tem algo de teatral, tirado em ruínas incas, detalhes que acrescentam para o observador desavisado ainda mais elementos que permitiriam considerar que se trata de um retrato quase etnográfico. $\mathrm{O}$ excesso de elementos que remetem simbolicamente à representação de um grupo ou etnia específica se dilui nesses dois únicos aspectos, uma vestimenta e um fragmento de ruína. Uma versão quase minimalista se for comparado ao retrato do menino índio, comentado anteriormente, tirado por Ferrez, ainda mais minimalista se considerar que elementos de construções incas faziam parte da paisagem urbana, principalmente em Cuzco, cidade onde o fotógrafo se estabeleceu. O olhar austero e suave e que, apesar do tronco levemente torcido do modelo, encara diretamente a câmara difere em muito do olhar plasmadamente rígido dos trabalhadores, dos escravos e do menino índio. Estes pareciam esvaziados de expressão, presos à própria rigidez de suas roupas/fantasias, presos à moldura invisível que o olhar do outro lhes impinge, como se seus acessórios e suas vestimentas não lhes pertencessem de verdade. $\mathrm{O}$ olhar de Chambi toma ares muito mais seguros de si e da foto; é um homem e um artista que parece ter relativamente bem definido o que quer e como quer ser visto em sua obra. É um mestiço de traços indígenas.

Essa visão entre as duas fotos talvez seja mediada pelo olhar de um espectador contemporâneo e que saiba o quanto as fotos de Chambi tentam mostrar os indígenas, os herdeiros da terra peruana, de uma forma não-caricaturizada; ou seja, elas promovem uma espécie de "limpeza" na estética do exótico estabelecida desde o período de descobrimento até o século XIX (quem sabe até hoje) e explorada de forma diferente em cada um desses momentos. Claro que esse olhar é passível de inserir conteúdos significativos através de uma releitura temporal. Este efeito, no entanto, também é fruto da distância criada pelo ato mesmo de tirar a foto, que estabelece o distanciamento entre o objeto retratado e o espectador, permitindo que se observem detalhes não previstos no momento que se toma a foto. Barthes ${ }^{14}$ e Sontag ${ }^{15}$ comentam a respeito desse efeito em suas obras sobre fotografia, como também deixam claro que os detalhes observados hoje são reflexos de nossa época. Chambi, apesar de ter vivido no começo do século, foi resgatado do esquecimento sob o título de um dos primeiros fotógrafos pós-coloniais; de alguma forma, isso torna sua obra passível de receber uma leitura voltada para essa visão.

Lucía Chiriboga, nascida em Quito, onde trabalha como diretora do "Taller Visual, Centro de investigações fotográficas e comunicação", por sua vez, produz um inventário de imagens baseadas em fotos antigas, documentos históricos e manipulação da imagem para obter uma expressão do que seria a identidade latino-americana a partir dos indígenas dos Andes equatorianos. As fotos comentadas aqui pertencem à série "Del fondo de la memoria, vengo". Sobre essa série Chiriboga afirma:

Se trata de una tentativa, a través de las técnicas de montaje o doble exposición, de rebasar los límites de la fotografía como documento, para aproximarme a factores subjetivos, culturales y de identidad. Una confluencia de lenguajes: vernacular, occidental, y mítico como una "metáfora impresa", inspirada en el juego de los tiempos largos de la cultura y en una reflexión 
sobre el proceso histórico de convivencia de las diversas culturas en el mundo andino. ${ }^{16}$

$\mathrm{Na}$ foto que se segue, à esquerda, tem-se uma espécie de retomada de posturas das fotos familiares alteradas pela releitura e trabalho de sobreposição de imagens de Chiriboga, na série mencionada, que passam a repercutir questões para além da continuidade sincrônica da família. A foto parece tentar claramente conectar-se com uma experiência passada, ver no presente da imagem ecos de um passado. Vê-se nela, em um plano mais evidente, uma casa em ruínas e uma mulher mais velha de ar senhoril e comandante, e de vestimentas populares. Tanto ela como a casa parecem compartilhar de uma mesma estética de fachadas decadentes. A casa tem ares de que em um passado remoto havia sido um grande espaço, mas as estruturas carcomidas pelo tempo só deixam ver a possível beleza áurea de um passado em contraposição à destruição do presente que a consome. Na mesma linha, a postura de comando da senhora aparece como resquício de um passado que não se reflete mais, nem por sua solidão nem pela aparente simplicidade das roupas. A solidão dela, no entanto, é apenas aparente. Sobreposta a essa imagem, vê-se uma legião de homens armados, aparentemente pertencentes a uma classe mais popular, que acompanham a mulher, como se ela fosse a matriarca de uma família há muito apagada pelo tempo. Fantasmas do passado povoam a memória e persistem ao redor de uma casa em óbvia decadência: o único que ainda segue inteiro é a mulher no centro da foto. A família se constitui de guerreiros que já não estão nem mais são, fazem parte de uma genealogia levemente apagada pelo tempo. Sua presença é um estar diluído pelo tempo. A relação entre fotografia e morte, explicitada por Barthes em sua obra, fica aqui evidente pela presença fantasmática dessa legião de soldados que foram no passado, mas que no presente, até mesmo da foto, não passam de sombras.

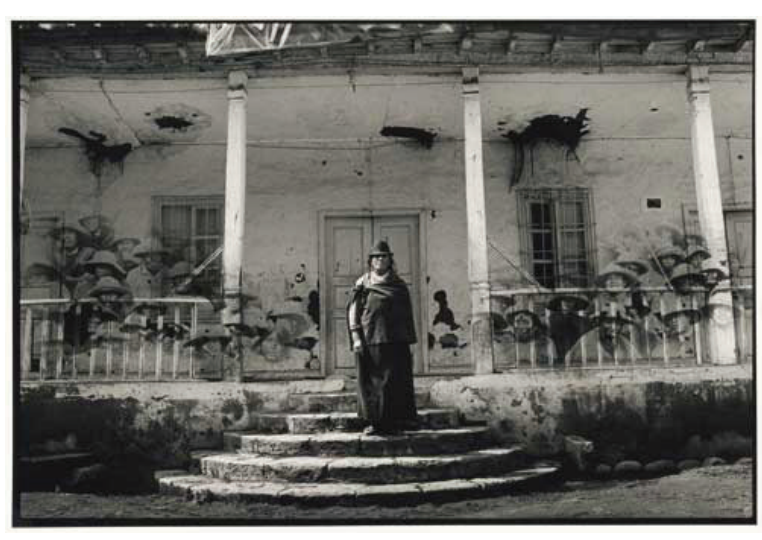

Sem título, "Del fondo de la memoria, vengo", Equador 1994-2003, Lucía Chiriboga ${ }^{17}$

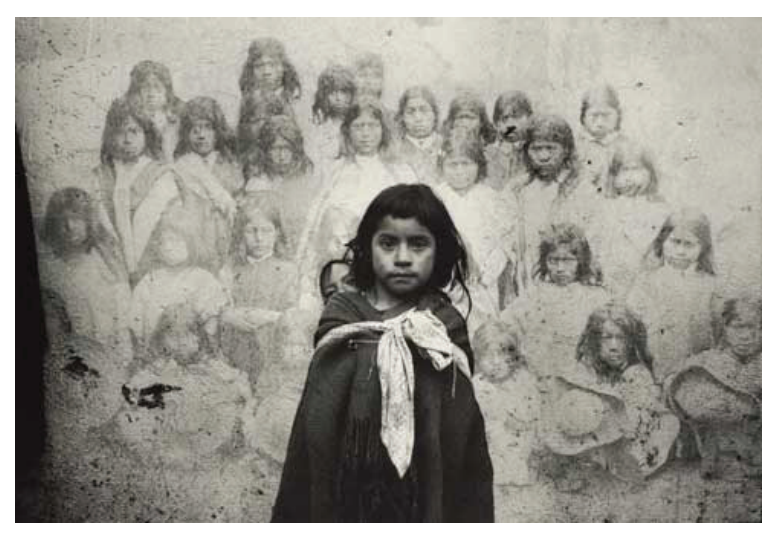

Sem título, "Del fondo de la memoria, vengo", Equador 19942003, Lucía Chiriboga

O mesmo processo pode ser observado em outras fotos, como na imagem acima; vê-se a foto de uma menina, tomada por Chiriboga, que aparece em primeiro plano, contrastando com e se integrando à foto mais antiga de um grupo de meninas no plano de fundo. As expressões são semelhantes, como se, descendente daquele grupo ao fundo, ela repetisse historicamente a mesma expressão: isso seria a própria herança e único legado desse passado. Por sua vez, a imagem que se encontra em segundo plano também emerge como um grupo de sombras, também fantasmas do passado. Conectadas e inseparáveis, essas meninas se ligam pelo tempo e se repetem nele como expressões de forças de um mesmo destino, que insiste em sua repetição ao longo da história. Nessa imagem de Chiriboga, o que vemos é uma reapresentação fantasmagórica, a foto antiga de trás, projetada na parede, remete àquele modelo de disposição das fotos de família. Nos dois casos, o amontoado de imagem do passado estabelece um elo de tradição, retomando não só poses e atitudes, mas também fotos antigas que, em jus- 
taposição, compõem uma espécie de relação de continuidade com o passado que se presentifica pelos fantasmas e figuras passadas expostas nas obras. A descontinuidade dessa aparente foto de família reflete algo semelhante às descontinuidades das fotos de Ferrez, Chambi e Christiano Junior, que também usam esse modelo, mas num contexto diferenciado.

O diálogo efetuado com as fotos desses fotógrafos do passado revela-se no aproveitamento de imagens antigas, que claramente não pertencem a esses artistas específicos, mas que compartilham com eles formas de representar o passado e as identidades na América Latina. Compartilhar essa herança de uma imagem cultural em projeções contemporâneas parece o caminho que a artista equatoriana encontrou para dialogar com expressões do passado; incorporar elementos passados e poses em/com fotos contemporâneas estabelece uma conexão direta com formas de representações anteriores. Em outra foto da mesma série, encontramos a sobreposição de uma fotografia de indígenas sobre um muro pichado e esburacado. A distribuição e organização do grupo se assemelha à da já mencionada foto de Marc Ferrez. O muro, no entanto, reincorpora essa imagem clássica de grupos nativos num contexto urbano e contemporâneo. Na foto abaixo, também podemos ver um processo semelhante de sobreposição de imagens.

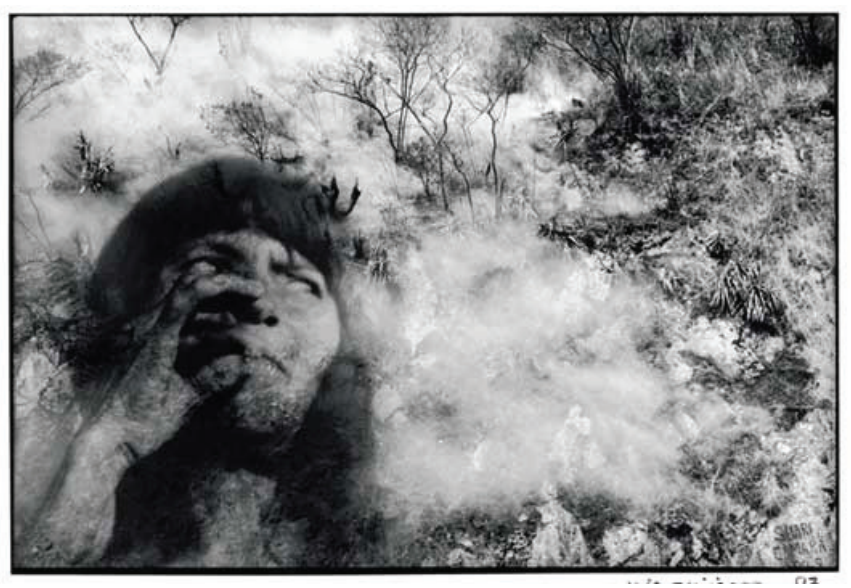

Sem título, "Del fondo de la memoria, vengo", Equador 1994-2003, Lucía Chiriboga

Nela, um retrato individual, se é possível chamá-lo assim, a foto de um índio é projetada sobre a foto de uma floresta em chamas. $\mathrm{O}$ índio parece estar fumando e as fumaças entre uma e outra foto criam uma estranha uni- dade. A foto também deve ter sido tomada de baixo para cima, criando um ângulo curioso. $\mathrm{O}$ índio não olha no mesmo nível do espectador (ainda que esse mesmo nível não indique uma postura direta para a câmera), ele olha mais para cima, como em transe, como se falasse com outros elementos. Diferente dos outros retratos, temos o símbolo aqui pela ausência máxima de elementos que remetem à identidade indígena, unicamente os traços. Por outro lado, a perda dos elementos que povoam de exotismo a figura do índio não é só uma postura estética e comprometida com o retrato fiel da realidade, também está relacionada com a perda concreta dos próprios símbolos. Trata-se de um processo de modificação de muitas culturas indígenas devido à convivência com a cultura ocidental em suas formas disponíveis na América Latina. A floresta destruída ou queimada nesse momento é tão símbolo desses povos e suas perdas e problemas quanto um cocar, uma pele de onça, uma flecha ou um balaio, jornais, máquinas de amolar.

Outra série, talvez mais radical em termos de usos de materiais diferenciados e sobreposições, se chama “Tenguel, el tamaño del tempo", que faz referência à lenda e ao território de Tenguel que evoca referências do passado de resistência local, tanto frente aos incas como frente aos espanhóis. Nesse projeto, mapas, documentos e fotos antigas são sobrepostas para reconstruir uma imagem, fragmentada, do presente. Essa imagem, no entanto, está em claro diálogo com o passado e suas referências.

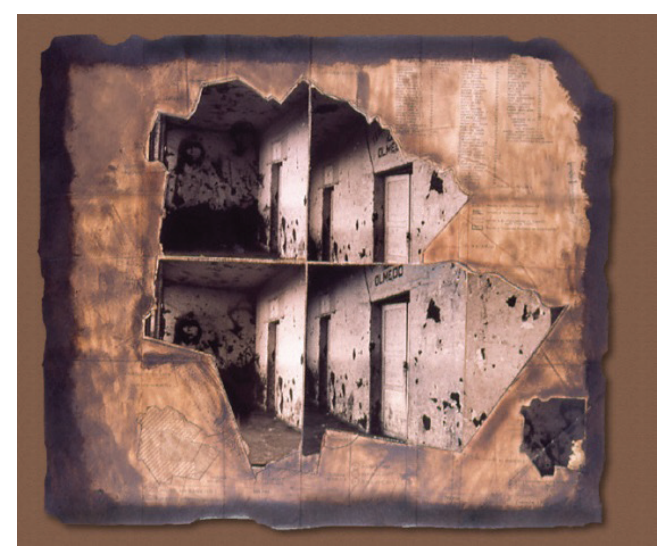

Memorias de culpas, "Tenguel, el tamãno del tempo", Equador

A foto "Memorias de culpas" é bastante curiosa nesse sentido porque usa um mapa do antigo território 
de Tenguel, mas com a parte do mapa efetivamente cortada. Através do vazado podemos ver quatro imagens do que parecem ser as ruínas de algum tipo de estabelecimento; nas fotos do lado esquerdo vemos outra vez as projeções de nativos nas paredes do local. Essas projeções evocam constantemente essa presença tão concreta como fantasmagórica do passado; concreta, porque é inegável, sua presença nas descendências não pode ser desmentida; e fantasmagóricas porque a herança e o vínculo com esse passado não é algo resolvido ainda na atualidade.

Pode-se dizer que as fotos de Christiano Junior, Ferrez e de Chambi apresentam uma sobreposição espacial e temporal involuntária, que revelam a expectativa do olhar do fotógrafo e do seu tempo na composição das poses e na aglutinação de elementos simbolicamente significativos para se compreender uma identidade do fotografado. Remetem ao passado pela forma como esperam ver os sujeitos retratados, como repetem suas poses, como repetidamente compõem uma quase pintura fotográfica. Já a técnica de Chiriboga leva ao limite essa sobreposição ao, factualmente, sobrepor elementos de diferentes origens e tempos causando uma perturbação e estranhamento semelhantes aos dois primeiros casos, ainda que completamente distintos. Os fantasmas desse passado estão duplamente na superfície da foto e em suas referências, como o Quixote de Pierre Menard, que era exatamente igual ao de Cervantes e, por isso mesmo, completamente distinto. Esse seria talvez o aporte do punctum barthesiano.

O contraste entre o punctum e o studium se constrói no espaço entre o previsível e o imprevisível. Isto se dá de duas formas, seja por captar elementos que não estavam previstos na conformação do studium, seja pelas imprevisíveis leituras e análises que se podem fazer ao longo da história de determinada imagem. Sobre essa imprevisibilidade se articulam histórias de anacronismo; sob a imagem imaginada pelo artista, studium, irrompem leituras já afastadas/distanciadas do objeto, seja porque se encontrem num tempo diferente, seja porque a fotografia realmente imprime distância entre o objeto observado e o espectador: é o punctum que rasga o tecido das imagens previstas e insere olhares individuais, marcados por espaços e tempos distintos.
Pensar o anacronismo ${ }^{18}$ como punctum é absorver a ideia da imprevisibilidade, foco principal do conceito em Barthes, e associá-la também à imprevisibilidade das leituras que se vão construindo ao longo da história de determinada imagem; seria dizer que o anacronismo também dependeria do espectador, ou seria principalmente construído por seu olhar. Ao observar as fotos, de Chiriboga, de Christiano Junior, de Ferrez e de Chambi, se tem a sensação de algo não exatamente adequado, fora do lugar, desconcertante. Num primeiro momento, parece que isso vem de uma tentativa explícita de captar, em uma imagem, reflexo de um mundo referencial, um fragmento de memória que surpreendesse os traços essenciais de uma representação ou identidade específica. Depois, se percebe que o processo de compreensão do studium e do punctum, nessas fotos analisadas, está associado à sobreposição de percepções, de tempos e de espaços.

De formas diferentes, os quatro fotógrafos captam esse princípio de tempo fugidio que se aloja nas imagens supostamente estanques de representação de tipos humanos como raça, identidades. Christiano Junior o faz, ao criar espaços de catalogação em constante diálogo com formas ulteriores de representar, mas, ao retomá-las, no espaço vazio do fundo branco de uma parede, acaba estabelecendo uma outra maneira específica de foto. Ferrez também o faz ao criar uma sobreposição espacial e temporal em que se observam elementos que o olhar decimonônico pressupõe como leitura de um índio, selvagem/decadente ou heroico, e como isso é traduzido através de formas conhecidas. Sua forma também retoma uma linha semelhante à de Christiano Junior ao retratar trabalhadores da cidade. Chambi o faz tentando captar uma identidade dos povos indígenas andinos que não seja exótica; por isso várias vezes ele os retrata em espaços altamente ocidentais, em que os traços de um possível exotismo, comum a uma geração anterior a sua, são reduzidos. Opta, assim, por um contraste com a presença dessas pessoas a partir de coisas simples como vestimentas até elementos menos palpáveis como os olhares. Já Chiriboga tem como projeto a sobreposição clara: a partir de fotos e documentos antigos e fotos de sua autoria, a fotógrafa monta um material que pretende captar e registrar o que os olhos 
não veem, criar metáforas vivas e palpáveis. A sobreposição é literal, e busca o que não pode ser visto a olho nu, coisa que só a sobreposição de olhares mediados por lentes poderia unir para dar significado. No entanto, as formas de retrato podem ser reconhecidas mesmo através da distorção, porque apagar o elo com o passado não faz parte daquilo que pleiteia a fotógrafa. A relação é evidente, mas evidentemente distorcida por um espaço de memória que altera a evocação dos fantasmas. O passado aqui é resquício, mas um resquício vivo de formas distintas no presente.

Considerando esses elementos como construtores de memória e como essas memórias aparecem através de técnicas diferentes nestes quatro artistas, vê-se nos trabalhos a presença, ao mesmo tempo, da tentativa de compreensão de uma identidade latino-americana e a incapacidade de apreensão desta mesma identidade: há sempre algo que perturba nesses trabalhos. Se as memórias na América Latina parecem construir-se a partir de caracteres diversos que evidenciam os processos deslizantes e mutáveis típicos dos processos de criação (invenção) da memória, as fotos de Christiano Junior, Marc Ferrez, Martín Chambi e Lucía Chiriboga trazem esses traços desestruturadores expostos por processos técnicos e plásticos diferentes que, entretanto, nesses casos, se desenvolvem em direção à concepção de Barthes de punctum como elemento atravessado pela ideia de anacronismo.

\section{Notas}

1. KOSSOY, Boris. Realidades e ficções na trama fotográfica. São Paulo: Ateliê Editorial, 2009.

2. BARTHES, Roland. A Câmara Clara: nota sobre fotografia. Tradução de Júlio Castañon Guimarães. Rio de Janeiro: Nova Fronteira, 1984.

3. CASTELNUOVO, Enrico. Retrato e sociedade na arte italiana: ensaios de história social da arte. Seleção de textos e coordenação de Sérgio Miceli. Tradução de Franklin de Mattos. São Paulo: Companhia das Letras, 2006.

4. CASTRO MORALES, Efraín. Los cuadros de castas de la Nueva España. Jahrbuch für Geschichte von Staat, Wirtschaft, und Gesellschaft Lateinamerikas, 20 (Köln, Böehlau Verlag, 1983) 671-690
5. Uso a foto de Witcomb como exemplo, pois o acervo em Buenos Aires com as fotos de Christiano Junior encontra-se sob o nome do primeiro.

6. As imagens de Marc Ferrez foram reproduzidas de REYNAUD, Françoise; TURAZZI, Maria Inez et alli. O Brasil de Marc Ferrez. São Paulo: Instituto Moreira Salles, 2005.

7. KOUTSOUKOS, Sandra Sofia Machado. Índios do Brasil pelas lentes de Marc Ferrez. In: LASA2010 Congress paper archive. Disponível em: http://lasa. international.pitt.edu/members/congress-papers/ lasa2010/files/2639.pdf.

8. Taca, Fernando de apud Koutsoukos, Sandra Sofia Machado. Índios do Brasil pelas lentes de Marc Ferrez. In: LASA2010 Congress paper archive. Disponível em: http://lasa.international.pitt.edu/members/congresspapers/lasa2010/files/2639.pdf.

9. Imagem reproduzida de TURAZZI, Maria Inez. Poses e trejeitos: a fotografia e as exposições na era do espetáculo (1839-1889). Rio de Janeiro: Rocco, 1995.

10. TURAZZI, Maria Inez. Marc Ferrez. São Paulo: Cosac \& Naify, 2000.

11. Imagem reproduzida de TURAZZI, Maria Inez. Marc Ferrez. São Paulo: Cosac \& Naify, 2000.

12. RANNEY, Edward apud ARAÚJO, Sabrina Moura de. O indigenismo sob o olhar de Martin Chambi. Disponível em: http://www.caminhosdamemoria. com/memo/martin_chambi.pdf.

13. Imagem extraída de http://www.elangelcaido.org/ fotografos/chambi/achambi06.html

14. BARTHES, Roland. A Câmara Clara: nota sobre fotografia. Tradução de Júlio Castañón Guimarães. Rio de Janeiro: Nova Fronteira, 1984.

15. SONTAG, Susan. Sobre fotografia. Tradução de Rubens Figueiredo. São Paulo: Companhia das Letras, 2004.

16. Chiriboga, Lucía. Del fondo de la memoria, vengo. Disponível em: http://www.homines.com/fotografia/ lucia_chiriboga/index.htm

17. Imagens de Lucía Chiriboga extraídas de http://www. homines.com/fotografia/lucia_chiriboga/index.htm

18. Para a ideia de anacronismo concebida como categoria de análise, consultar o prólogo de CORDIVIOLA, Alfredo. O império dos antagonismos: escrita e imagem no ocaso da dominação espanhola na América. Recife: PPGL-UFPE, 2010. 


\section{Referências}

ARAÚJO, Sabrina Moura de. O indigenismo sob o olhar de Martin Chambi. Disponível em: <http://www.caminhosdamemoria.com/memo/martin_chambi.pdf $>$. Acesso em: 16 set. 2010.

BARTHES, Roland. A Câmara Clara: nota sobre fotografia. Tradução de Júlio Castañon Guimarães. Rio de Janeiro: Nova Fronteira, 1984.

BRIENEN, Rebecca Parker. Albert Eckhout: visões do paraíso. Tradução de Julio Bandeira. Rio de Janeiro: Ed. Capivara, 2010.

BORGES, J. L. "Kafka y sus precursores". In Obras completas.: 1923-1972. Buenos Aires: EMECÉ, 1974. p. 710712.

CASTELNUOVO, Enrico. Retrato e sociedade na arte italiana: ensaios de história social da arte. Tradução de Luiz Fernando Franklin de Mattos. São Paulo: Companhia das Letras, 2006.

CASTRO MORALES, Efraín. Los cuadros de castas de la Nueva España. Jahrbuch für Geschichte von Staat, Wirtschaft, und Gesellschaft Lateinamerikas, Köln, 20, p. 671-690, 1983. Disponível em: <http://www.lrc.salemstate.edu/hispanics/other/Los_cuadros_de_castas_de_la_Nueva_Espana_Castro.pdf $>$. Acesso em: 25 mar. 2011.

CHIRIBOGA, Lucía. Del fondo de la memoria, vengo. Disponível em: <http://www.homines.com/fotografia/lucia_chiriboga/index.htm>. Acessado em: 18 set. 2010.

CORDIVIOLA, Alfredo. O império dos antagonismos: escrita e imagem no ocaso da dominação espanhola na América. Recife: PPGL-UFPE, 2010.

GUTIÉRREZ, Ramón (org.). Pintura, escultura y artes útiles en Iberoamérica (1500-1825). Madrid: Cátedra, 1995.

GUTIÉRREZZ VIÑUALES, Rodrigo e GUTIÉRREZ, Ramón (org.). Pintura, escultura y fotografía en Iberoamérica (siglos XIX y XX). Madrid: Cátedra, 1997.

KOSSOY, Boris. Realidades e ficções na trama fotográfica. São Paulo: Ateliê Editorial, 2009.

KOUTSOUKOS. , Sandra Sofia Machado. Índios do Brasil pelas lentes de Marc Ferrez. Disponível em: $<$ LASA2010 Congress paper archive. Disponível em: http://lasa.international.pitt.edu/members/congresspapers/lasa2010/files/2639.pdf $>$. Acesso em: 6 mai. 2011.

SONTAG, Susan. Sobre fotografia. Tradução de Rubens Figueiredo. São Paulo: Companhia das Letras, 2004.

SOUGEZ, M. L. História da fotografia. Tradução de Lourenço Pereira. Lisboa: Dinalivro, 2001.
REYNAUD, Françoise; TURAZZI, Maria Inez et alli. $O$ Brasil de Marc Ferrez. São Paulo: Instituto Moreira Salles, 2005.

TURAZZI, Maria Inez. Poses e trejeitos: a fotografia e as exposições na era do espetáculo (1839-1889). Rio de Janeiro: Rocco, 1995.

Maria Inez. Marc Ferrez. São Paulo: Cosac \& Naify, 2000.

ZEA, Leopoldo. El pensamiento latinoamericano. Barcelona: Ariel, 1976. Disponível em: <http://www.ensayistas.org/filosofos/mexico/zea/pla/>. Acessado em: 10 mar. 2011.

Recebido em: 20/04/2014 Aceito em: 06/07/2014 
